\title{
Tedaviye dirençli Anti-LGI1 ilişkili otoimmün ensefalit olgusu
}

\section{A case with treatment resistant Anti-LGl1 related autoimmune encephalitis}

\author{
Selin Betaş, Göksemin Demir
}

Gönderilme tarihi:08.03.2021

Kabul tarihi:29.03.2021

\section{Öz}

Anti-LGı1ilişkili otoimmün ensefalit hafıza kusuru, çeşitli nöropsikiyatrik semptomlar, davranış bozuklukları ve nöbetler gibi limbik sistemin tutulumuna işaret eden klinik belirtilerle karakterizedir. Nöbetler genel olarak antiepileptik ilaçlara dirençlidir. Ancak immün tedavi ile oldukça dramatik bir nöbet kontrolü sağlanabilir. Burada sunulan 67 yaşındaki erkek hasta dirençli sol fasiobrakial distonik nöbetler nedeniyle ile başvurmuştur. LGI1 otoantikoru pozitif olan ve kognitif defisit tespit edilen hasta, kısa süreli immün tedavilerden fayda görmüşse de 3 ay içinde başlayan nöbet nüksü ve kognitif kötüleşme ancak uzun süreli immünsupresyon ile kontrol altına alınabilmiştir. Bu olgu bazında anti-LGI1 ilişkili otoimmün ensefalitin prezentasyonu, tanısı ve bazı dirençli vakalarda uzun süreli immunsupresif tedavinin nöbet kontrolüne ve kognitif düzelmeye katkısının vurgulanmıştır.

Anahtar kelimeler: Otoimmünensefalit, epilepsi, nöbet, steroid.

Betaş S, Demir G. Tedaviye dirençli Anti-LGI1 ilişkili otoimmün ensefalit olgusu. Pam Tıp Derg 2022;15:197-200.

\begin{abstract}
Anti-LGI1 associated autoimmune encephalitis is characterized by cognitive deficits, various neuro-psychiatric symptoms, behavioral disorders and seizures that point to involvement of the limbic system. Seizures are frequently resistant to antiepileptic medications, however they can be dramatically controlled by immunological treatment modalities. In our case, a 67-year-old male patient presented with refractory epilepsy. His left fasciobrachial dystonic seizures recurring several times a day were patognomonic for anti-LGI1 associated encephalitis. Besides frequent seizures, he also had significant cognitive deficit. Short term immune therapies improved cognition and he remained seizure free for 3 months. Unfortunately, after 3 months his seizure frequency and cognitive problems increased gradually. In this case report, we discussed the presenting features and diagnosis of antibody-LGI1 autoimmune encephalitis and emphasized the contribution of long term immunosuppressive therapy to seizure control and cognitive improvement.
\end{abstract}

Key words: Autoimmuneencephalitis, epilepsy, seizure, steroid.

Betas S, Demir G. A case with treatment resistant Anti-LGI1 related autoimmune encephalitis. Pam Med J 2022;15:197-200.

\section{Giriş}

Otoimmün ensefalitler subakut başlangıçlı bellek bozukluğu, konfüzyon ve sık nöbetlerle karakterize paraneoplastik ya da immünolojik etyolojiye sahip bir grup sendromdur. Epilepsiden hareket bozukluklarına, psikoza kadar değişen klinik spektrumda giderek artan sayıda otoimmün ensefalit formları tanımlanmaktadır. Lösin açısından zengin glioma-inaktive 1(LGI1) antikor ensefaliti, voltaj kapılı potasyum kanal kompleksi (VGKC) antikorlarına eşlik eden bir otoimmün ensefalittir. Spesifik olarak bir antinöronal yüzey antijeni veya antisinaptik protein ile ilişkilidir. Bilişsel bozukluk, nöbetler ve psikiyatrik bozukluklar gibi otoimmün ensefalitin yaygın semptomlarına ek olarak, bu hastalık aynı zamanda fasiyobrakial distonik nöbet (FBDN) ve refrakter hiponatremi tablosu ile karşımıza çıkabilmektedir. LGI-1 ensefaliti genellikle immun tedaviye çok iyi yanıt veren bir tip olmakla birlikte nadiren tedaviye dirençli nöbetler görülebilmektedir. Bu olgu sunumunun amacı, nadir görülen bu otoimmun ensefalitte antiepileptiklere dirençli nöbetlerin kontrolünde sürekli immunsupresif tedavinin nöbet kontrolüne ve kognitif düzelmeye katkısını vurgulamaktır.

\section{Olgu sunumu}

67 yaşında erkek hastanın 1 hafta önce başlayan sol kolda istemsiz kasılma ve o esnada sol yüz yarısında da kasılma şikayeti

Selin Betaş, Arş. Gör. Dr. Pamukkale Üniversitesi Tıp Fakültesi, Nöroloji Anabilim Dalı, Denizli, Türkiye, e-posta: selin_betas@hotmail.com (https:// orcid.org/0000-0002-7372-2907) (Sorumlu Yazar)

Göksemin Demir, Prof. Dr. Pamukkale Üniversitesi Tıp Fakültesi, Nöroloji Anabilim Dalı, Denizli, Türkiye, e-posta: goksemind@yahoo.com (https:// orcid.org/0000-0001-8068-9060) 
nedeniyle çekilen kraniyal MRG'si normal ve EEG'si epileptiform aktivite ile uyumlu saptanması üzerine fokal başlangıçlı nöbet tedavisi başlanmış. Kademeli olarak titre edilen levetirasetam tedavisi daha sonra lakozamid ve zonisamid ile kombine edilmesine rağmen nöbet kontrolü sağlanamayan hastanın sol kolundaki istemsiz kasılmaya bilinç kaybının da eklenmesi üzerine tetkik amaçlı tarafımıza yönlendirilmiş. Yapılan nörolojik muayenesi ve rutin laboratuvar incelemeleri normal olan hastanın özgeçmişinde bilinen ek bir hastalığı yoktu. Yatarak takibi sırasında bilinç kaybının eşlik etmediği fasiobrakial bölgede birkaç saniye sürüp geçen distonik kasılmalar gözlemlendi. Eş zamanlı skalp video EEG'sinde distonik hareketten birkaç milisaniye önce ortaya çıkan sağ frontal lob kaynaklı epileptik aktivite kaydedildi (Şekil 1). Hastanın tanımlanan nöbetleri ile zamansal olarak ilişkili kognitif yakınmalarının da olması nedeniyle yapılan nöropsikolojik testlerinde (NPT) özellikle sözel ve görsel bellekte, kayıt, depolama ve geri çağırmada orta/ileri derecede, dikkatte ise belirgin bozulma tespit edildi. Viral ve paraneoplastik etyolojinin ayırımı ve olası epileptik odağın tespiti amacıyla yapılan beyin PET-BT görüntülemesinde sol posterior singulat kortekste, sağ anterior singulat kortekste, sağda belirgin olmak üzere bilateral inferior frontal giruslarda multipl odaklar halinde fokal hipometabolizma alanları saptandı. Lomber ponksiyon yapılan hastanın BOS bulguları total protein yüksekliği dışında olağandı. Çoklu antiepileptik tedaviye rağmen dirençli nöbetleri olan hastanın paraneoplastik ve malignite taraması negatifti ancak otoimmün ensefalit taramasında anti LGI-1 otoantikoru pozitif saptandı (Titre 1:320). Otoimmün ensefalite yönelik önce 5 gün boyunca intravenöz immünglobulin (IVIG) tedavisi verildi. Kısmen nöbet kontrolü olsa da tam remisyon sağlamak amacıyla 3 hafta sonra 10 gün 1 gr/gün i.v. metilprednizolon tedavisi uygulandı. IVIG ve i.v. metilprednizolon tedavisinden sonra nöbet kontrolü yaklaşık 3 ay sağlandı. Daha sonra giderek sıklaşan fokal nöbetler ve1 kez jeneralize tonik klonik nöbet geçirmesi, başlangıçta azalan ancak daha sonra tekrar artış gösteren kognitif yakınmaları nüks olarak değerlendirildi. Yapılan kontrol NPT' sinde öncekine göre bellek fonksiyonlarında kötüleşme olması üzerine tekrar 10 gün $1 \mathrm{gr}$ iv metilprednizolon tedavisi uygulandı. Nöbet kontrolü sağlandıktan sonra $80 \mathrm{mg}$ oral prednizolon idamesi ile taburcu

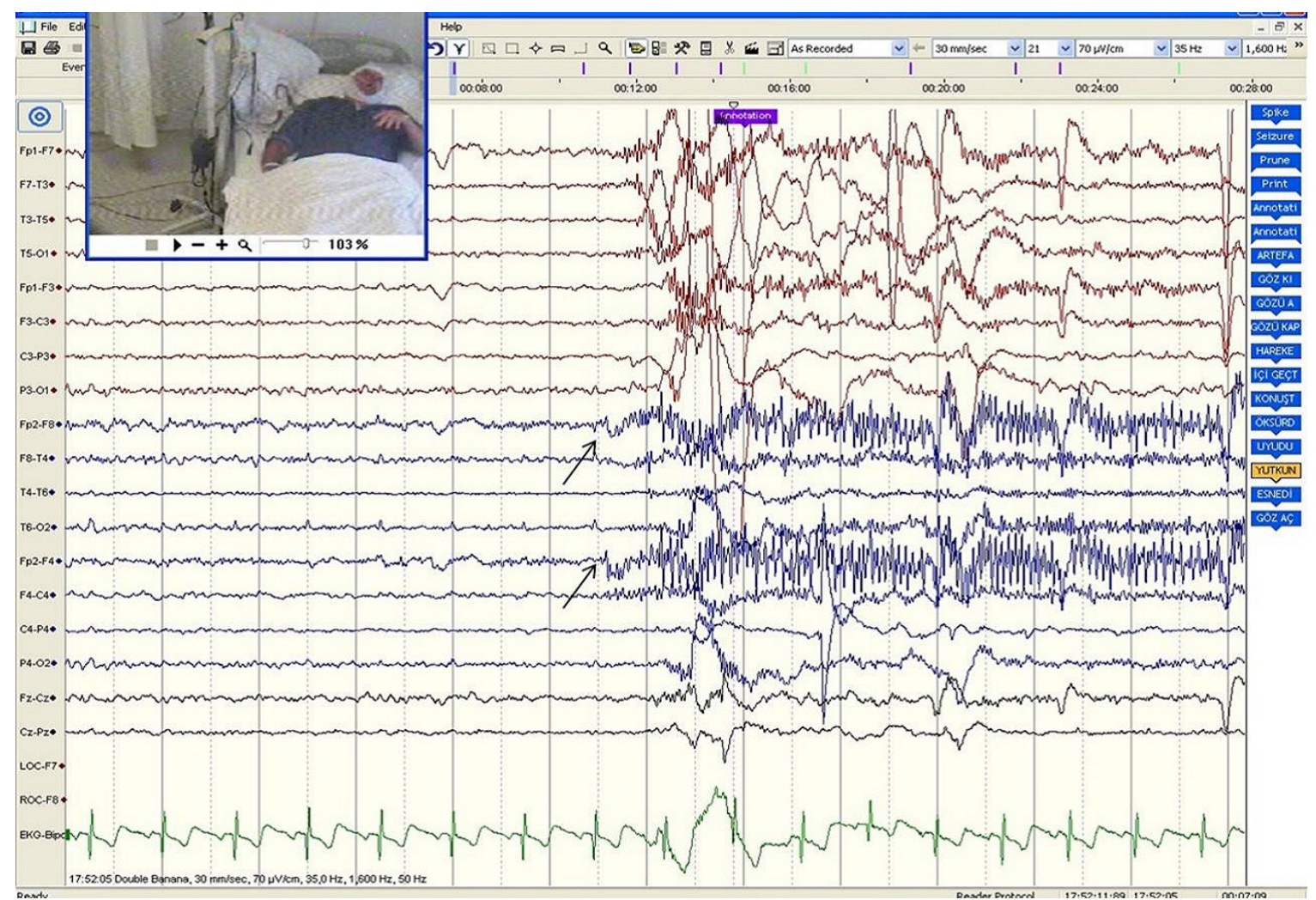

Şekil 1. Hastanın çekiminde sık sık sol kolunda tonik kasılma izlenmiştir

Bu kasılmalarda yaklaşık 1/2 sn. önce sağ F8-T4 elektrotlarında tonik deşarjlar izlenmiştir

Sonuç olarak, Sağ frontal bölge kaynaklı epileptik anormallikle uyumludur (Siyah ok ile gösterilmiştir) 
edildi. Takip süresince hastanın tekrar nöbeti olmadığı için prednizolon tedavisi kademeli olarak azaltılarak 16mg/gün'e kadar düşüldü. En son yapılan NPT'sinde öncekine göre kayıt ve depolamanın düzeldiği ancak diğer bulgularda belirgin fark olmadığı tespit edildi.

\section{Tartışma}

Otoimmün ensefalitler subakut başlangıçlı bellek bozukluğu, konfüzyon ve sık nöbetlerle karakterize paraneoplastik ya da immünolojik etyolojili bir grup sendromdur [1]. LGI1, ligand işlevi görerek AMPA reseptör aracılı sinaptik sinyal iletimi kontrolünde görevli bir proteindir. Çoğunlukla hipokampal bölge ve temporal kortekste bulunmaktadır [2]. Anti LGI-1 otoimmün ensefalitli hastalarda nöbet yaygın bir bulgudur ve FBDN'ler, mezial temporal lob epilepsisine benzeyen nöbetler hem fokal hem de sekonder jeneralize tonik klonik nöbetler şeklinde görülebilir. FBDN hastaların yaklaşık yarısında görülebilmekte ve Anti LGI-1 ensefaliti için çok spesifik olduğu düşünülmektedir [3]. $\mathrm{Bu}$ nöbetler çok kısa (<3 sn), tek taraflı kol ve ipsilateral yüz yarısında distonik postür olacak şekilde istemsiz kasılmalardır ve günde 100 defaya kadar tekrar edebilir [3, 4]. Ayrıca hastalarda kognitif fonksiyonlar da etkilenmekte olup nöropsikolojik testlerde özellikle sözel ve görsel-uzamsal epizodik bellek performansında kötüleşme, sözel akıcılık ve depolamada bozulma, gecikmiş serbest hatırlama ve geri çağırmada zorlanma bulguları gösterilmiştir. Önemli hafıza güçlükleri genellikle hipokampusun yapısal bütünlüğündeki değişikliklerle ilişkilendirilmiş ve hastalığın kronik evrelerinde ortaya çıktığı bildirilmiştir [5]. Bunun yanında apati, ajitasyon, depresyon, halüsinasyon gibi birçok psikiyatrik bozukluk eşlik edebilmektedir [6]. Anti -LGI1 ensefalitli olgularda beyin PET-BT görüntülemeleri incelenmiş ve limbik ensefalit evresindeki hastaların \%70-75'inde bazal ganglionlarda ve \%63-70'inde mediotemporal bölgelerde (daha sık hipermetabolizma olmak üzere) hiper/hipometabolizma alanları saptanmıştır [5]. Olgumuzda nüks sonrası kognisyonda kötüleşme olup literatür ile karşılaştırdığımızda nöropsikolojik test bulguları literatürü destekleyicidir ancak beyin PET-BT'de farklı tutulum alanları saptandığı göze çarpmaktadır. $\mathrm{Bu}$ ensefalit tablosunda immünsupresif tedavi intravenöz veya oral kortikosteroidler, IVIG veya her ikisinin kombinasyonu şeklinde uygulanır. Genellikle immünoterapi ile klinikte önemli iyileşme görülebilmekte ve kognisyonda bozulma önlenebilmektedir [7, 8]. Fakat olgumuzda da olduğu gibi immünoterapiye dirençli vakalar mevcuttur. Shen ve ark.'nın [9] çalışmasında anti-NMDAR, anti-LGI1 ve anti-GABA ${ }_{B} R$ ensefaliti olan toplam 119 hastada, hastaların 83'ünün $(\% 69,7)$ yeni başlangıçlı nöbetler geliştirdiği, takipler sonunda 80 hastanın 17'sinde $(\% 21,3)$ nöbet remisyonundan sonra nöbet nüksleri olduğu veya epilepsiye dönüştüğü bulunmuştur. Anti -NMDAR, anti -LGI1 ve anti -GABA ${ }_{B} R$ ensefaliti olan hastalarda immünoterapinin gecikmesi ve interiktal epileptik deşarjların epilepsi gelişimi ile ilişkili olduğu tespit edilmiştir. Tüm bu etkenler göz önüne alındığında dirençli epilepsilerde ayırıcı tanıda özellikle otoimmün ensefalitlerin akılda tutulması gerekir. Hızlı tanı ve tedavi nöbetlerin epilepsiye dönüşmesini engellemede kritik öneme sahiptir. Her ne kadar çoğu vaka kısa süreli immun tedavilerle remisyona girse de anti LGI-1 otoimümmün ensefalitli bazı olgularda nöbet tekrarının olması ve kognitif kötüleşme durumunda uzun süreli immünoterapiye geçmek gerekli olabilir.

Çıkar ilişkisi: Yazarlar çıkar ilişkisi olmadığını beyan eder.

\section{Kaynaklar}

1. Goodfellow JA, Mackay GA. Autoimmune encephalitis. J R Coll Physicians Edinb 2019;49:287-294. https://doi. org/10.4997/JRCPE.2019.407

2. Li Z, Cui T, Shi W, Wang Q. Clinical analysis of leucinerich glioma inactivated-1 protein antibody associated with limbic encephalitis onset with seizures. Medicine (Baltimore) 2016;95:e4244. https://doi.org/10.1097/ MD.0000000000004244

3. Andrade DM, Tai P, Dalmau J, Wennberg R. Tonic seizures: a diagnostic clue of anti-LGI1 encephalitis? Neurology 2011;76:1355-1357. https://doi.org/10.1212/ WNL.0b013e3182152808

4. Irani SR, Michell AW, Lang B, et al. Faciobrachial dystonic seizures precede LGI1 antibody limbic encephalitis. Ann Neurol 201;69:892-900. https://doi. org/10.1002/ana.22307

5. Griffith SP, Malpas CB, Alpitsis R, O'Brien TJ, Monif M. The neuropsychological spectrum of antiLGI1 antibody mediated autoimmune encephalitis. J Neuroimmunol 2020;345:577271. https://doi. org/10.1016/j.jneuroim.2020.577271 
6. Li X, Yuan J, Liu L, Hu W. Antibody-LGI 1 autoimmune encephalitis manifesting as rapidly progressive dementia and hyponatremia: a case report and literature review. BMC Neurol 2019;19:19. https://doi. org/10.1186/s12883-019-1251-4

7. Irani SR, Gelfand JM, Bettcher BM, Singhal NS, Geschwind MD. Effect of rituximab in patients with leucine-rich, glioma-inactivated 1 antibody-associated encephalopathy. JAMA Neurol 2014;71:896-900. https://doi.org/10.1001/jamaneurol.2014.463

8. Shin YW, Lee ST, Shin JW, et al. VGKC-complex/ LGI1-antibody encephalitis: clinical manifestations and response to immunotherapy. J Neuroimmunol 2013;265:75-81. https://doi.org/10.1016/j. jneuroim.2013.005

9. Shen $\mathrm{CH}$, Fang $\mathrm{GL}$, Yang $\mathrm{F}$, et al. Seizures and risk of epilepsy in anti-NMDAR, anti-LGI1, and anti-GABA $R$ encephalitis. Ann Clin TransI Neurol 2020;7:13921399. https://doi.org/10.1002/acn3.51137

Hasta onamı: Yazılı hasta onamı hastadan alınmıştır.

\section{Yazarların makaleye olan katkıları}

G.D. ve S.B. çalışmanın ana fikrini ve hipotezini kurgulamışlardır. Makalenin tartışma bölümü S.B. tarafından yazılmış, G.D. gözden geçirip gerekli düzeltmeleri yapmış ve onaylamıştır. Ayrıca tüm yazarlar çalışmanın tamamını tartışmış ve son halini onaylamıştır. 